\title{
Akademisyen olmak: Genç akademisyenlere öneriler ${ }^{*}$
}

\section{Being an academician: Suggestions to young academicians}

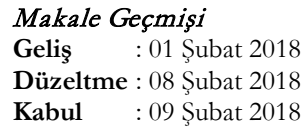

Makale Türü

Düşünce Yazısı
Article History

Received : 01 February 2018

Revised : 08 February 2018

Accepted : 09 February 2018

\section{Article Type}

Opinion Paper

\author{
Meziyet $A r{ }^{1}$
}

Öz: Yüksek Öğrenim kurumlarında bilimsel araştırmalar ile alana katkıda bulunan kişilere akademisyen denir. Akademisyenliğe giden ilk yol ilgi duyulan alanda yüksek lisansa başlamaktır. Daha sonra yine ilgi duyulan alanda ve iyi olduğu düşünülen bir üniversitede doktora programına kayıt yaptırılır. Danışman ile akademisyen adayı arasında uyum sağlanmalıdır. Problemler oluştuğunda, yeni çözüm yolları bulunmalıdır. Doktora eğitiminden sonra akademisyen olma ya hak kazanılır. Akademisyen, alandaki bilgisini arttırmak için, yurtdışındaki literatür hakkında bilgi sahibi olmalıdır. Bu yüzden yabancı dil hâkimiyeti çok önemlidir. İyi bir akademisyen öğrencileriyle ve iş arkadaşlarıyla iyi sosyal ilişkiler geliştirir. Ülke içinde ve dışında yapılan kongrelere katılır ve alanda sosyal çevresini genişletir Ayrıca yayın sayısını artırmaktan çok kaliteli yayın çıkarmak ve alana katkıda bulunmak önemlidir

Anahtar Kelimeler: Akademisyen olmak, tavsiyeler

Abstract: People who contribute to the any field through scientific researches in higher education institutions are called academicians. The first step towards becoming an academic is to start a master's programme in a field of interest. Then, enrolling in a Ph.D. programme is necessary. Harmony between the supervisor and the candidate academic should be ensured. If problems emerge, new solutions should be created. After the successful completion of the Ph.D. programme, the candidate is eligible to become an academic. The academic must be able to follow international academic literature, therefore, proficiency in a foreign language is extremely important. A qualified academic develops social networks with students and colleagues, and participates to academic congresses, both national and international. Furthermore, since making contributions to the field is necessary, quality of the articles is more important than their quantity.

Keywords: Being an academician, suggestions

\footnotetext{
* 5.Uluslararası Okul Öncesi Eğitim Kongresinde "Panel konuşması” olarak sunulmuştur.

${ }^{1}$ Bilgi Üniversitesi, meziyet.ari@bilgi.edu.tr
} 


\section{GÍRIŞ \\ “Uygarlığımızın geleceği bilimsel düşünme alışkanlığımızın gitgide yayılmasına ve derinleşmesine bă̆lıdır." John Dewey}

Bilindiği gibi “akademisyen” üniversite ve benzeri yükseköğrenim kurumlarında öğretim faaliyetlerini gerçekleştiren, araştırma yapan ve özgün araştırmalarıyla alanına katkıda bulunan kişilere verilen genel mesleki unvandır. Bu unvanı hak edebilmek ve sürdürebilmek için bazı bireysel özelliklere sahip olmak gerekir. Bu özellikler arasında düşünmek, meraklı olmak, sorgulamak, araştırmak, çalışmayı sevmek ve sabırlı olmak başta gelir.

\section{Akademisyenliğe Giden Yol}

Eğer akademisyen olmayı hedeflediyseniz, lisans öğrenimini tamamladıktan sonra ilk basamak alanınıza veya ilgi duyduğunuz yakın bir dalda açılan yüksek lisans programına başvurmak ve koşulları yerine getirerek kayıtlanmak öncelikli adımınız olmalıdır. Bazı akademisyen adayları öğrenim gördükleri bilim dalı dışında başka bir alana da ilgi duyabilmektedir. $\mathrm{Bu}$ yol daha zahmetli olsa da muhtemelen açık bir yoldur. Bilimsel hazırlık adı altında ilgi duyduğunuz alanın gerekli derslerini tamamlayarak tercihiniz olan yeni alanda yüksek lisans yapabilme olanağını değerlendirebilirsiniz. Yüksek lisans programına devam ettiğiniz yıllar, akademik yaşama karşı duygularınızı ve isteklerinizi belirleyecektir. Akademisyenliğe giden ana yol ise bir doktora programını tamamlamaktan geçer.

\section{Akademisyenlik Gerçek Hedefiniz mi? Geçici Bir Heves mi?}

Niçin istiyorsunuz? Meraklı, sabırlı, azimli misiniz? Yüksek lisans tezinizi yazarken neler hissetiniz? Bir an önce bitirme arzunuzun temelinde, araştırmanızın sonuçlarına olan merakınız mı, yoksa sıkıcı bulduğunuz ve gerginlik hissettiren çalışma temposundan kurtulmak mı yatıyor? Hedefinizi belirlerken öncelikle kendinizi tanımalısınız. Doktora programına başlamadan güçlü ve güçsüz yanlarınızı değerlendirin.

\section{Doktora Programı Seçerken}

Bazı üniversitelerin bazı alanlarda daha nitelikli eğitim ve öğretim sürdürdüğü bilinmektedir. Alanınızın iyi olduğu bilinen bir üniversite araştırın. Yurt içi olduğu gibi yurt dışı imkânlarını ve bursları takip edin. Alt yapınızı güçlendirin ve yabancı dile ağırlık verin. Yirmili yaşlar, beynin öğrenme kapasitesinin yüksek olduğu; ileriki yıllara oranla daha az çaba, daha fazla kazanımların olduğu dönemdir. Akademik yaşam yabancı dil öğrenmeyi gerektirir. Bunu önemseyin, sürekli okuyun ve dinleyin. Alanınızla ilgili yabancı literatürü izleyin. Literatüre 
ulaşımın çok zor olmadığı yıllarda doktora çalışmasını sürdüren biri olarak bunun kıymetini bilmeli ve sürekli okumalısınız. Literatür takibi uygun tez konusu seçmenizde size en yararlı yol gösterici olacaktır.

\section{Uygun Tez Konusu Seçmek}

- $\mathrm{Bu}$ evrede her kademedeki tez öğrencisi genellikle zorlanır. Size birden fazla konu ilginç gelebilir. Araştırma projenizi seçerken sakin olmak ve ilgi duyduğunuz konulara ait çok sayıda makale okumak yolunuzu aydınlatacaktır.

- Seçtiğiniz araştırmayı önce kendiniz sorgulamalısınız.

- Sonra yakın çevrenizde güvendiğiniz kişilerle paylaşabilirsiniz.

- Eleştiriler tezin niteliğini artırabilir, yapıcı eleştirilerden yararlanın.

- Araştırma konusu ile beraber bir danışman seçme imkânını iyi değerlendirmek önemlidir.

- Danışmanlar bazı bölümlerde doğrudan doktora adayına bildirilir. Böyle bir durumda danışmanla tez konusu seçimini beraber yapmanız daha uygun olacaktır.

- İyi bir danışman, seçtiğiniz konuya vakıf, size zaman ayırabilecek, sizi teşvik edecek bir akademisyendir. Danışman - öğrenci ilişkisi, her zaman verimli yürümeyebilir. Danışman ile tez öğrencisi arasında uyumlu bir birliktelik olmayabilir. Mizaç farkları, beklentilerin karşılık bulamaması gibi nedenlerle tezin verimli ilerleyemediği durumlar olabilir. Benzer uyumsuzluk durumlarında danışman değiştirmek veya tezin konusu gereği ikinci bir ortak danışmanı talep etmek mümkündür. Bunu yapan ve başarıyla tezini tamamlayanların yanında, tez yazmayı bırakıp doktora programını terk edenler de olmuştur.

\section{Üniversitede Hoca Olmak}

Alanımızda doktora yapan meslektaşlarımızın öncelikli hedefi genellikle iyi bir üniversitede öğretim üyesi olmaktır. Bu evre genç akademisyenlerin mutlu ve heyecanlı oldukları bir zaman dilimini kapsar. Doktora yaptıkları üniversitede öğretim üyesi olarak kalma talepleri olabilir ancak bu her zaman mümkün olmayabilir. $\mathrm{Bu}$ durumda size ihtiyacı olan üniversiteleri saptamak, her birinin özelliklerini ve koşullarını detaylıca incelemek önemlidir. Üniversitenin devlet veya vakıf olma özelliğine göre sunduğu imkânları, konumunu ve bölümdeki diğer akademik personeli, dolayısıyla muhtemel rekabet ortamını değerlendirmek yararlıdır. Ayrıca alternatifleri düşünmek, ekonomik durumunuzu, beklentilerinizi, üniversite dışında bir çalışma 
hayatının size sunacağı imkânları gözden geçirerek karar vermek önemlidir. Mesleğinizi nerede yaparsanız yapın en iyi şekilde yapmaya gayret ederseniz fark yaratan biri olmaya adaysınızdır.

\section{Sosyal İlişkiler}

Akademik dünyada sosyal ilişkiler önemlidir. İdareciler, arkadaşlar, öğrencilerle ilişkilerde her zaman dikkatli olmak ve nezaketi korumak, rahatsızlık üretecek ortamları engeller. Akademisyenler öğrencileri için birer rol modelidir. İlkeli ve adil olmak, gençlerin ihtiyaçlarına duyarlı olmak önemlidir.

\section{Ö̆̆rencilerle ilişkiler}

Öğrencileriniz için birer rol modeli olduğunuzu düşünerek davranışlarınızda ilkeli ve adil olmalısınız. Sizden değişik konularda yardım talebinde bulunabilirler, bu talepleri karşılamak mümkün olmasa bile yol gösterici önerileriniz olmalıdır. Korkulan bir hoca olmak yerine sevilen ve güven duyulan bir hoca olmak ileriki y1llarda size gurur verici şekilde geri dönecektir. Bu gururu yaşamak akademisyenliğin en doyum sağlayıcı unsurlarının başında gelir. Korku uyandıran bir hoca bazı alanlarda bireysel rahatlık sağlayabilir fakat iyi bir akademisyene iç huzuru hissettirmez.

\section{Arkadaşlarla İlişkiler}

Bulunduğunuz ortamda sizden önce aynı göreve başlayan meslektaşlarınız olduğu gibi sizden sonra gelen daha genç elemanlar da olacaktır. Farklı yörelerden, farklı kişilik özellikleriyle gelen gençlerin en azından aynı bilimsel alana ilgi duymak ve o alanda çalışmak gibi bir ortak noktaları bulunmaktadır. Bu özellik, olumlu yaklaşımlarla genç meslek elemanlarını yakınlaştırıcı ve sinerji verici bir etki yaratabilir. Olumlu akademik ortamlar, hem bireysel hem de kurumsal üretim ve gelişime temel oluşturur. Ne yazık ki akademik rekabet olumlu ortamları bile zaman zaman sarsabilir. Böyle durumlarda bireysel sürtüşmelerden, kişiliğe yönelik agresif çıkışlardan kaçınmak, olumsuz yaklaşım gösterenlerden uzak durmak gerilimin tırmanmasını önleyebilir.

\section{Sosyal Băğlantılar}

Akademik yaşamda sosyal bağlantılar her meslekte olduğundan daha fazla önem taşır. Bilimsel kuruluşlara üye olmak, konferanslara ve kongrelere katılmak, yeni araştırmalardan ve fikirlerden haberdar olmak mesleki gelişiminizde size önemli katkılar sağlayacaktır. Özellikle, alanınızda düzenlenmiş yurt içi yıllık kongrelere düzenli olarak katılmanız meslektaşlarınızla birlikteliğinizi ve fikir alış verişlerinizi geliştirecek, size yeni bakış açıları kazandıracaktır. Yurt dışı kongre katılımlarınız için de fırsatları değerlendirin her ihtimale karşı imkanlarınız 
ölçüsünde bütçenizde bu kaleme az da olsa yer açmanızı öneririm. Bu harcamanızın farklı biçimlerde geri dönüşümü sizi fazlasıyla memnun edebilir.

\section{Zaman Kullanımını Denetlemek}

Akademik yaşamın zorluklarından biri zaman kullanımıyla ilgilidir. Akademik çalışmanın mesai saatleri yoktur. Akademisyenlerin zihinleri sürekli son araştırma bulgularının niteliği, makalesinin iyi bir dergiden yayın kabulü alıp almaması, bir üst akademik unvanı için yapması gerekenler ve benzeri mesleki düşüncelerle doludur. Bunların yanında, eş, çocuk, anne, baba gibi aile ile ilgili özel sorunlar ve sorumluluklar birikim gösterince ağır bir yük altında olduğu hissine kapılan genç akademisyenler arasında ruhsal ve bedensel sorunlarla baş etmek zorunda kalanlar az değildir. Stresimizi kontrol altında tutabilmenin etkili yollarından biri rahatlatıcı hobiler geliştirmek, sanat ve spora vakit ayırabilmektir. Bunları vakit kaybı olarak değerlendirmenin ve vaktim boşa gitmesin saplantısıyla sürekli bilgisayar başında çalışmanın, zamanı verimli geçirdiğinizi zannetmenin maliyeti ağır olabilir. Bilimsel çalışmalar oyun ve sporun her yaş döneminde zihinsel gelişim ve bedensel sağlık açısından yararını ortaya koymaktadır. Ortak hobileriniz olan arkadaşlarınızla beraberliğiniz sizi rahatlatacak ve ürettiklerinizin niteliği artacaktır.

\section{Kalite mi, Yayın Sayısı mı?}

Doçentlik dosyalarını incelerken bazı adayların çok sayıda benzer yayın yaptıkları dikkat çekicidir. Kabarık klasörler göz doldurucu olabilir ancak yayınlar incelendikçe benzer düzeyde, fazla bilimsel katkı getirmeyen, birbirinin tekrarı niteliğindeki çalışmalar çoğu zaman değerlendiriciyi sıkar ve hoşnutsuzluk yaratır. Oysa bazı klasörler fazla kabarık olmamakla beraber orijinal ve bilimsel katkıları olan araştırma makaleleri ile doyurucu ve memnuniyet vericidir. Yayın sayısını artırmak amaçlı yapılan çalışmalar derhal kendini belli eder. $\mathrm{Bu}$ nedenle zaman içinde nitelikli olmayan yayınlar yerine daha az da olsa doyurucu ve bilimsel katkısı olan yayınlar tercih edilmelidir. İçinize sinmeyen çalışmalarınızı yayınlamayın, ileride sizi rahatsı edebilir.

Yukarıda yazıya dökülen görüşler 5. Okul Öncesi Eğitim Kongresi’nde bir panelde sunulmuştur.

Katılımcıların merakları arasında panelistlerin hedefleri arasında akademisyenliğin olup olmadığı sorusu vardı. Benim yanıtım:

Akademisyenlik saygınlığı olan bir uğraşı alanıdır. Başlangıçta doğrudan hedeflemesem de zaman içinde yöneldiğimi fark ettim. İstanbul Üniversitesi’nden 1968 yılında Pedagog olarak 
mezun oldum ve Kütahya Öğretmen Okulu'na meslek dersleri öğretmeni olarak atandım. Bu görevim sadece üç ay sürdü. Ankara'da Hacettepe Üniversitesi Tıp Fakültesi'nden gelen bir teklifi kabul ederek naklen tayinimi istedim ve 1968 y1lında Hacettepe'de pedagog olarak göreve başladım. Bu görevi sürdürürken Ankara Üniversitesi Eğitim Fakültesi Eğitimde Psikolojik Hizmetler Bilim Dalı'nda yüksek lisans programına kayıtlandım. 1972 yılında ise Hacettepe Üniversitesi Sağlık Bilimleri Enstitüsü’nün açtığı Çocuk Gelişimi ve Eğitimi Bilim Dalı doktora sınavını kazanarak doktora çalışmalarıma başladım.1973 yılında da Çocuk Gelişimi ve Eğitimi Bilim Dalı'nda açılan asistanlık sınavını kazandım ve bu bölümde uzun yıllar severek görev yaptım. Ocak 1977 yılında doktoramı aldığımda, alanın Türkiye'deki ilk doktoralı akademisyeni olmanın hazzını yaşadım, aynı özellik doçentlik ve profesörlük unvanlarını edinmemde de devam etti. Hemen arkamdan gelen arkadaşlarımla beraber uzun yıllar çok özverili çalıştık. Akademik çalışmalarımız arasında okulöncesi eğitimi yaygınlaştırma büyük yer aldı. Gazi Üniversitesi’nde Okul Öncesi Öğretmenliği Bölümü açıldığında 4 yıl, Ankara Üniversitesi'nde de 5 yıl görevli öğretim üyesi olarak destek verdim. Kısaca özetlersek, yaşam bazen bizi beklenmedik, başlangıçta hedeflemediğiniz farklı ve güzel mecralara yöneltebilir. Tek koşul yeterli bir alt yapı ve istekli olmaktır. 